\title{
Effect of Egyptian Propolis Extract as an Adjuvant with Irradiated Cancer Vaccine against Ehrlich Ascites Carcinoma in Mice
}

\author{
S. F. Salama\# and A. A. Hassan \\ Radiation Biology Dept., National Centre for Radiation \\ Research and Technology (NCRRT), P. O. Box; 29 Nasr City, \\ Egypt. ${ }^{\#}$ E.mail; Salamafaried@Yahoo.com.
}

\begin{abstract}
DROPOLIS is a non-toxic natural substance with multiple pharmacological properties including anti-cancer and antioxidant. The objective of this study was to investigate the effect of Egyptian propolis extract (Prop) as an adjuvant coinjected with irradiated tumour cell lysate vaccine (Irr-V) against Ehrlich ascites carcinoma (EAC) in mice. Animals were divided into five equal groups $(\mathrm{n}=10)$. Control group. EAC group; injected with viable EAC $\left(2 \times 10^{5} /\right.$ mouse $)$ in the right thigh. EACProp group; injected subcutaneously (Sc) with Prop $(0.4 \mathrm{mg} /$ mouse) weekly for three times, then after 2 weeks mice were received EAC viable cells (the day of challenge). Irr- $\mathrm{V}$ group; vaccinated with irradiated EAC cell lysate weekly for three times at a dose of $0.2 \mu \mathrm{l}$ in the right thigh. Prop-Irr- $\mathrm{V}$ group; vaccinated as Irr-V group, and treated with Prop as EAC-Prop group. Two weeks post the last treatment; animals of groups 4 and 5 were challenged with normal viable EAC $\left(2 \times 10^{5} /\right.$ mouse $)$ in the opposite thigh. Results: The results revealed a decrease in red blood cells (RBC) count, haematocrite value (Hct) and haemoglobin content $(\mathrm{Hb})$ and an increase in total leucocytes, absolute lymphocyte and neutrophil counts in EAC-bearing mice. Furthermore, oxidative stress identified by a decrease in glutathione (GSH) content and superoxide dismutase (SOD) activity associated with an increase in the content of advanced oxidation protein products (AOPP) and malondialdehyde (MDA) were recorded in the liver and blood tissues of EACbearing mice. Propolis, Irr-V as well as Irr-V-Prop treatment improved haematological toxicities and oxidative stress in EACbearing mice. However, improvement was more pronounced in Irr-V-Prop group and the cell viability assay, the tetrazolium dye;3-(4,5-dimethylthiazol-2-yl)-2,5-iphenyltetrazolium (MTT) showed a significant decrease in viable cells compared to each treatment alone. It could be concluded that Prop extract might be used as an adjuvant for irradiated cancer vaccines in cancer therapy.
\end{abstract}

Keywords: Egyptian propolis, cancer vaccine, Ehrlich ascites carcinoma, mice. 
Propolis is a mixture of plant resins and bee secretions collected by honeybees and characterized by multiple pharmacological properties and healthcare functions (Zhang et al., 2013). Bees gather propolis from diverse resinous plant parts and in different phytogeographic regions (Popova et al., 2013). The biological properties of propolis are related to its chemical composition and more specifically to the phenolic compounds that vary in their structure and concentration depending on the region of production, availability of sources to collect plant resins, genetic variability of the queen bee, the technique used for production, and the season in which propolis is produced (Toreti et al., 2013). Propolis possesses beneficial biological effects, including antimicrobial (Scazzocchio et al., 2006), antioxidant (Valente et al., 2011) anti-inflammatory (Tan-No et al., 2006), anticancer (Orsolic et al., 2006) and immunostimulant (Sforcin, 2007).

A combination of immunotherapy with chemotherapy, radiotherapy and surgery for cancer is an emerging challenge and an emerging paradigm, in contrast to the concept that defines most standard treatments as immunosuppressive (Ridolfi et al., 2010). Anti-cancer vaccination strategies are already focused on combination with other immunotherapeutic strategies (Andersen et al., 2008). Cancer vaccines act for stimulating an immune response as a mean of combating cancer encompasses a number of approaches, including whole tumour cell vaccines, tumour-extracted protein vaccines, tumour antigen vaccines, dendritic cells (DCs)-mediated vaccines, and tumour antigen-encoding virus vaccines. Most cancer vaccines are designed to be therapeutic vaccines (Pecorino, 2005). Cancer cellular vaccines can be packed in at least three forms; DCs, Autologous or allogenic tumour cells and TumourAPC hybrids (Delgado, 2002). These vaccines can be delivered alone or with adjuvants ( $\mathrm{Li}$ et al., 2009). The first cancer vaccines were composed of irradiated tumour cells, being modelled after successful attenuated pathogen vaccines (Pecorino, 2005). There is no standard dose of gamma-irradiation with which it could be pre-treat tumour cells in vitro prior to their use in a vaccine. Previous studies have used gamma radiation ranging from 25 to $200 \mathrm{~Gy}$. By using gamma irradiation, the tumour cells lose their proliferative function (Deacon et al., 2008). Propolis has been suggested to be a promising adjuvant substance in duck inactivated vaccines (Cai et al., 2001). Total ethanolic

Egypt. J. Rad. Sci. Applic., Vol. 27, No. 1-2 (2014) 
extracts of green propolis have been shown to improve humoral and cellular immune responses in mice inoculated with an inactivated vaccine against bovine herpes-virus type 5 (Fischer et al., 2007).

The study aims to investigate the effect of propolis co injected with Irr-V against EAC in mice. Cell viability assay, haematological profile, GSH contents and SOD activities in blood and liver were determined. AOPP, MDA concentrations were assessed in serum and liver.

\section{Materials and methods}

\section{Experimental animals}

Fifty adult male mice, weighing ( $24 \pm 2 \mathrm{~g}$ ) were obtained from the Nuclear Research Centre (NRC), Atomic Energy Authority, Anchas, Egypt. Mice were allowed to acclimate in metal cages inside a well-ventilated room for 2 weeks prior to the commencement of the experiment. They were maintained under standard laboratory conditions, were fed a standard commercial pellet diet and water ad libitum. Animals were randomly divided into five equal groups $(\mathrm{n}=10)$. Control group; normal healthy mice. EAC group; injected with viable EAC (2x105/mouse) in the right thigh. EAC-Prop group injected Sc with Prop $(0.4 \mathrm{mg} / \mathrm{mouse})$ weekly for three times, then after 2 weeks mice were received EAC viable cells (the day of challenge). Irr-V group; vaccinated with irradiated EAC cell lysate weekly for three times at a dose of $0.2 \mu 1$ in the right thigh. Prop Irr-V group; vaccinated as Irr-V group and treated with Prop as EAC-Prop group. Two weeks post the last treatment animals of groups 4 and 5 were challenged with normal viable EAC $\left(2 \times 10^{5} /\right.$ mouse $)$ in the opposite thigh.

\section{Ethanol extraction of Prop}

Prop was purchased from the Local market. The ethanol extraction was performed according to Najafi et al. (2007) with modification. In the first step Prop was extracted by ethanol, Prop (90g) was added into $400 \mathrm{ml}$ of $96 \%$ ethanol and mixed for $18 \mathrm{~h}$ at $15^{\circ} \mathrm{C}$. The mixture was then centrifuged at 7000 $\mathrm{rpm}$ for $15 \mathrm{~min}$ at $20^{\circ} \mathrm{C}$. The supernatant was collected and the pellet was reextracted with $100 \mathrm{ml}$ ethanol. After pooling the supernatants of both steps, they were used for the experiments.

Egypt. J. Rad. Sci. Applic., Vol. 27, No. 1-2 (2014) 
Cell Line of EAC; Mus muscles which is a fibroblast like in shape (Sato et al., 1961) was obtained from the National Cancer Institute (NCI), Cairo university. The cells were propagated as ascites in female Swiss albino mice after intra peritoneum inoculation.

\section{Radiation facility}

Different doses of gamma rays (2KGy, $4 \mathrm{KGy}$, 6KGy or $8 \mathrm{KGy}$ ) were examined and $8 \mathrm{KGy}$ dose was chosen to precede the experiment and given at a dose rate of $0.49 \mathrm{~Gy} / \mathrm{min}$. Irradiation was performed at NCRRT, using a Gamma Cell-40 $\left({ }^{137}\right.$ Cesium) biological irradiator manufactured by the Atomic Energy of Canada Ltd, Ottawa, Ontario, Canada.

\section{Vaccine prepared from tumour cell lysate}

EAC cells were lysed according to method Schnurr et al. (2001) with modification. Briefly, Cells were incubated with $0.01 \%$ EDTA solution for 10 min. The cells were washed twice in PBS, and re-suspended at a density of $5 \times 10^{6} / \mathrm{ml}$ in serum-free medium. The cell suspensions were frozen at $80^{\circ} \mathrm{C}$ and disrupted by four freeze-thaw cycles. For the removal of crude debris, the lysate was centrifuged for $10 \mathrm{~min}$ at $300 \mathrm{xg}$. The mice were injected by supernatant cell lysate.

\section{MTT assay}

MTT assay was assessed according to Freimoster et al. (1999) with modification. Briefly, $300 \mu \mathrm{l}$ of MTT solution $(0.5 \mathrm{mg} \mathrm{MTT} / \mathrm{ml})$ were added to each well and incubated in $5 \% \mathrm{CO}_{2}$ incubator for $4 \mathrm{hrs}$. Cells were pelleted by centrifugation $(15,000 \mathrm{xg})$ for $5 \mathrm{~min}$. The media were removed. $500 \mu \mathrm{L}$ of mixture Isopropanol $/ \mathrm{HCl}$ were added $(2 \mathrm{ml}$ of $0.1 \mathrm{~N} \mathrm{HCl}$ in $23 \mathrm{ml}$ isopropanol). The samples were vortexed vigorously and the absorbance (abs) was measured at $560 \mathrm{~nm}$. The viability was calculated. The percentage of viable cell $=$ sample abs/control absx 100. Spleen was removed from animal immediately after dissection; each spleen was placed into RPMI medium. Then spleen was disaggregated. The spleenocytes were poured from strainer to remove any debris then centrifuged for $7 \mathrm{~min}$ at $600 \mathrm{xg}$ at room temperature. The pellet was flicked gently and re-suspended in $10 \mathrm{ml}$ RPMI media (Rowland-Jones and McMichael, 2000).

Egypt. J. Rad. Sci. Applic., Vol. 27, No. 1-2 (2014) 


\section{Blood sample collection and haematological and oxidative stress assays}

Two blood samples were immediately collected by heart puncture. The first sample was collected in heparinised tube $(2.25 \mu \mathrm{L}$ heparin $/ 5 \mathrm{ml}$ blood $)$ for haematological assays. The second blood sample was centrifuged at 1000xg for $10 \mathrm{~min}$, to collect the serum which was stored at $-20^{\circ} \mathrm{C}$ until analyzed. The liver was dissected out and washed. For oxidative stress biomarkers, a known weight of the organ was used to obtain a $10 \%$ tissue homogenate in $0.15 \mathrm{M} \mathrm{KCl}$. Blood picture was investigated using an automated haematology analyzer (BC2800vet; Mindray, China). GSH content was measured by spectrophotometer at $412 \mathrm{~nm}$ (Beutler et al., 1963). SOD activity was determined according to the method of Minami and Yoshikawa (1979). Lipid peroxidation is based on the determination of MDA which reacts with thiobarbituric acid in acidic medium to yield a pink coloured trimethine complex at $532 \mathrm{~nm}$ (Yoshioka et al., 1979). AOPP were measured by spectrophotometer on a microplate reader at $340 \mathrm{~nm}$ (Witko-Sarsat et al., 1998).

\section{Analysis of data}

The results are presented as percentage and mean \pm S. E. Statistical analysis was performed using one-way analysis of variance (ANOVA), statistical package of social science (SPSS) version 15.0 for windows. Individual difference among groups was analysed by Duncan's test. Significance was accepted at $P<0.05$.

\section{Results}

EAC-bearing mice showed a significant decrease in $\mathrm{Hb}$ content and $\mathrm{Hct}$ value and $\mathrm{RBC}$ count compared with normal control group. In Irr-V Group, $\mathrm{Hb}$ content and Hct value and RBC count were increased significantly $(P<0.05)$ compared with EAC- group. Prop $(0.4 \mathrm{mg} /$ mouse $)$ co-injected Irr-V $(0.2 \mu \mathrm{l}$ of cell lysate, 3 weeks) in EAC-bearing mice elevated significantly the decrease in $\mathrm{Hb}$ content and Hct value and RBC count compared to EAC and Irr-V groups (Table 1). EAC-bearing mice showed a significant increase in total leukocyte, neutrophil, and lymphocyte counts compared to control group. In Irr-V Group, total leukocyte, neutrophil and lymphocyte counts were decreased significantly as compared with EAC group. Prop co-injected with irradiated tumour cell lysate vaccine in EAC-bearing mice decreased significantly $(P<0.05)$ the Egypt. J. Rad. Sci. Applic., Vol. 27, No. 1-2 (2014) 
increase in total leukocyte, neutrophil, lymphocyte counts as compared to EAC and Irr-V groups (Table 1).

TABLE I. Leucocyte, neutrophil, lymphocyte $\left(x 10^{3} / \mathrm{mm}^{3}\right)$ and RBC $\left(\times 10^{6} / \mathrm{mm}^{3}\right)$ counts and Hb content and Het values in the different groups.

\begin{tabular}{|c|c|c|c|c|c|}
\hline Groups & Control & EAC & Irr-V & EAC-Prop & Prop-Irr-V \\
\hline RBC & $6.3 \pm 0.5$ & $3.8 \pm 0.2^{\text {acd }}$ & $4.8 \pm 0.3^{\text {bd }}$ & $4.5 \pm 0.3^{\mathrm{d}}$ & $5.9 \pm 0.3^{\text {bc }}$ \\
\hline Hb $(\mathrm{g} / \mathrm{dl})$ & $14.4 \pm 0.9$ & $8.1 \pm 0.5^{\text {acd }}$ & $10.4 \pm 0.7^{\text {bd }}$ & $9.7 \pm 0.7^{\mathrm{d}}$ & $12.7 \pm 0.7^{\mathrm{bc}}$ \\
\hline Hct $(\%)$ & $32.6 \pm 1.5$ & $19.4 \pm 1.2^{\text {acd }}$ & $23.9 \pm 1.6^{\mathrm{bd}}$ & $23.2 \pm 1.7^{\mathrm{d}}$ & $29.9 \pm 1.6^{\mathrm{bc}}$ \\
\hline Leucocytes & $6.1 \pm 0.5$ & $11.1 \pm 0.8^{\text {acd }}$ & $8.8 \pm 0.5^{\mathrm{bd}}$ & $8.5 \pm 0.8^{\mathrm{b}}$ & $6.8 \pm 0.5^{\mathrm{bc}}$ \\
\hline Neutrophils & $1.3 \pm 0.1$ & $3.2 \pm 0.2^{\text {acd }}$ & $1.9 \pm 0.1^{\mathrm{b}}$ & $2.4 \pm 0.2^{\mathrm{b}}$ & $1.5 \pm 0.1^{\mathrm{bc}}$ \\
\hline Lymphocytes & $4.8 \pm 0.4$ & $7.9 \pm 0.5^{\text {acd }}$ & $6.6 \pm 0.4^{\mathrm{bd}}$ & $5.9 \pm 0.6^{\mathrm{b}}$ & $4.9 \pm 0.4^{\mathrm{bc}}$ \\
\hline
\end{tabular}

a:significance with control, b: significance with EAC, c: significance with Irr-V, d: significance with Prop-Irr-V.

Data in Table 2. showed that EAC-bearing mice showed a significant decrease in blood GSH concentration and SOD activity and significant $(P<0.05)$ increase in serum AOPP and MDA contents compared to control group. Irr-V Group showed significant decrease in contents of serum AOPP and MDA as well as significant increase GSH level, SOD activity as compared to EAC-bearing mice. Combination treatment of Prop (0.4 mg/ mouse) as an adjuvant with Irr-V $(0.2 \mu \mathrm{l}$ of cell lysate, 3 weeks $)$ against EAC in mice reduces significantly AOPP, MDA concentrations and enhances significantly GSH content and SOD activity as compared to EAC and Irr-V group.

TABLE 2. Blood GSH content, SOD activity and serum MDA and AOPP levels in the different groups.

\begin{tabular}{|c|c|c|c|c|c|}
\hline Groups & Control & EAC & Irr-V & EAC-Prop & Prop-Irr-V \\
\hline GSH $(\mathrm{mg} / \mathrm{dl})$ & $35.8 \pm 1.4$ & $21.7 \pm 1.8^{\text {ad }}$ & $25.9 \pm 1.0^{\text {bcd }}$ & $25.1 \pm 1.0^{\mathrm{d}}$ & $30.3 \pm 1.5^{\text {bcb }}$ \\
\hline SOD $(\mathrm{U} / \mathrm{ml})$ & $5.3 \pm 0.3$ & $2.6 \pm 0.2^{\text {ad }}$ & $3.2 \pm 0.3$ & $3.8 \pm 0.4^{\text {bd }}$ & $4.5 \pm 0.5^{\text {bc }}$ \\
\hline AOPP $(\mu \mathrm{mol} / \mathrm{l})$ & $26.3 \pm 2.1$ & $39.2 \pm 2.4^{\text {acd }}$ & $33.4 \pm 1.8^{\text {bd }}$ & $31.0 \pm 1.6^{\mathrm{b}}$ & $27.6 \pm 1.8^{\text {bc }}$ \\
\hline MDA $(\mathrm{nmol} / \mathrm{l})$ & $46.1 \pm 1.6$ & $70.7 \pm 2.3^{\text {acd }}$ & $53.9 \pm 1.8^{\text {bd }}$ & $56.2 \pm 1.9^{\text {bd }}$ & $47.9 \pm 1.3^{\text {bc }}$ \\
\hline
\end{tabular}

Legends as in Table 1.

Data in Table 3. showed that EAC-bearing mice showed a significant decrease in liver GSH concentration and SOD activity and significant increase in liver AOPP and MDA as compared to control group. Irr-V Group showed significant decrease in contents of serum AOPP and MDA as well as significant increase GSH level, SOD activity as compared to EAC-group. Combination treatments EAC in mice inhibit significantly $(P<0.05)$ AOPP, MDA

Egypt. J. Rad. Sci. Applic., Vol. 27, No. 1-2 (2014) 
concentrations and enhances significantly GSH content and SOD activity as compared to EAC and Irr-V groups.

TABLE 3. Hepatic GSH \& MDA levels (nmol/g tissue) and SOD (U/ g tissue) activity and $\mathrm{AOPP}(\mu \mathrm{mol} / \mathrm{g}$ tissue $)$ in the different groups.

\begin{tabular}{|c|c|c|c|c|c|}
\hline Groups & Control & EAC & Irr-V & EAC-Prop & Prop-Irr-V \\
\hline GSH & $24.8 \pm 1.5$ & $14.5 \pm 1.3^{\text {acd }}$ & $19.2 \pm 1.4^{\mathrm{b}}$ & $19.4 \pm 1.1^{\mathrm{bcd}}$ & $23.4 \pm 1.7^{\mathrm{bc}}$ \\
\hline MDA & $185.4 \pm 3.1$ & $223.6 \pm 4.3^{\text {acd }}$ & $204.1 \pm 4.7^{\text {bd }}$ & $197.9 \pm 4.5^{\mathrm{b}}$ & $190.9 \pm 3.6^{\mathrm{bc}}$ \\
\hline SOD & $126.0 \pm 3.1$ & $103.8 \pm 3.0^{\text {acd }}$ & $118.2 \pm 3.4^{\mathrm{bd}}$ & $122.0 \pm 2.6^{\mathrm{b}}$ & $128.8 \pm 2.8^{\mathrm{bc}}$ \\
\hline AOPP & $206.1 \pm 6.7$ & $267.3 \pm 4.7^{\text {acd }}$ & $243.2 \pm 4.8^{\mathrm{bd}}$ & $246.3 \pm 6.1^{\mathrm{bc}}$ & $225.7 \pm 5.2^{\mathrm{bc}}$ \\
\hline
\end{tabular}

Legends as in Table 1.

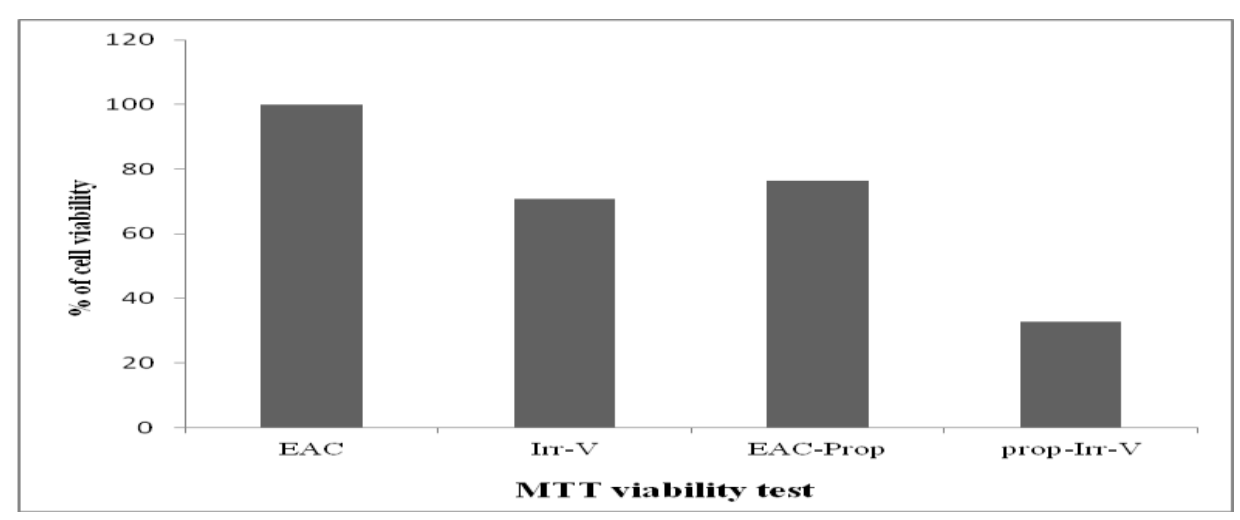

Fig.1. MTT viability test in different groups.

The MTT results in Fig.1. showed a decrease in the cell viability in animals treated with Prop, irradiated tumour vaccine alone as compared to EAC-group. In combination treatment, MTT showed a significant decrease in viable cells compared to each treatment alone.

\section{Discussion}

In the present study, anaemia occurs in tumour-bearing mice represented by significant reduction in $\mathrm{RBC}$ count, $\mathrm{Hb}$ content and Hct value. These findings corroborate previous results (Badr et al., 2011 and Pandya et al., 2013). This may occur either due to iron deficiency or due to haemolytic or other myelopathic conditions (Shivhare et al., 2011) such as suppressive effect of EAC cells on bone marrow erythropieosis (DeGOwin and Gibson, 1978). Granulocytic leucocytosis that was observed might be due to the acute inflammatory response or stress due to the proliferation of EAC cells (Hashem et al., 2004).

Egypt. J. Rad. Sci. Applic., Vol. 27, No. 1-2 (2014) 
EAC-induced oxidative stress represented by significant decrease in the SOD activity and GSH level in blood and liver tissues and increased in AOPP and MDA in serum and liver of EAC bearing mice. Gupta et al. (2001) demonstrated that reduction in several antioxidant defence mechanisms correlates with the emergence of the malignant phenotype. The implication of free radicals in tumours is well documented (Ravid and Korean, 2003). The observed decrease in the SOD activity in EAC bearing mice might be due to the loss of the Mn SOD activity in EAC cells and loss of mitochondria, leading to a decrease in the total SOD activity in the liver (Sun et al., 1989). SOD-anions $\left(\mathrm{O}_{2}-\right)$ to $\mathrm{H}_{2} \mathrm{O}_{2}$ and protects the cells against $\left(\mathrm{O}_{2}-\right)$ mediated lipid peroxidation. MDA, the endproduct of lipid peroxidation, was reported to be higher in tumour tissues than in non diseased organs (Yagi, 1987). GSH is a major non-protein thiol required for the proliferation and metabolism of tumour cells (Guruvayoorappan and Girija Kuttan, 2007). GSH is regulator of protein synthesis, DNA synthesis and cell proliferation (Suthanthiran et al., 1990). Moreover, some amino acid precursors for GSH synthesis have been shown to be essential in cancer metabolism, e.g. glutamine (Moreadith and Lehninger, 1984) and methionine (Hoffman, 1985). The decrease in GSH content in EAC-bearing mice occurred through impaired GSH synthesis, which is associated with an increase in oxidized glutathione. Peroxide production by tumour cells-can lead to GSH oxidation within the red blood cells and different tissues (Badr El-Din, 2004). This may occur due to the decreased transport activity of the oxidized GSH through membranes with a decrease in the activity of glutathione reductase which is augmented by riboflavin deficiency (Abou-Bedair et al., 2002).

The Prop-treated mice bearing EAC at the doses of $0.4 \mathrm{mg} / \mathrm{mouse}$ ameliorated the haematological parameters. The extract also reduced the elevated levels of lipid peroxidation and AOPP and increased the GSH content and SOD activity in EAC-treated mice. It was reported that Prop-containing antioxidant principles depends mainly on the presence of flavonoids (Nakajima et al., 2009) that have been reported to enhance immune system (Wleklik et al., 1987). Two main immune potent chemicals of propolis have been identified as caffeic acid phenethyl ester (CAPE) and artepillin C. Propolis, CAPE, and artepillin $\mathrm{C}$ have potential antitumor properties by different postulated mechanisms such as suppressing cancer cells proliferation via its anti-

Egypt. J. Rad. Sci. Applic., Vol. 27, No. 1-2 (2014) 
inflammatory effects; decreasing the cancer stem cell populations; blocking specific oncogene signaling pathways; exerting antiangiogenic effects and modulating the tumour microenvironment (Chan et al., 2013). The decrease of live cells could be due to the interference of propolis constituents with the growth of EAC cells directly during the early phase of treatment and leading to a considerable elimination of these cells (Orsolic et al., 2005). Increased lymphocyte proliferation lead to enhance macrophage activation and thus an amplification of general immunological responses (Stuehr and Nathan, 1989). Antitumor activity of these antioxidants is either through induction of apoptosis (Ming et al., 1998) or by inhibition of neovascularization (Keshavarz et al., 2009). The free radical hypothesis supported the fact that the antioxidants effectively inhibit the tumour (Ravid and Korean, 2003).Thus, the present findings indicate that the ethanol extracts of propolis contain components that may have anticancer activity (Ishihara et al., 2009). phenolic acid esters are present $(72.7 \%)$ in a major quantity in Prop (Abdel-Hady, 1994).

Irradiated cancer vaccine treated animals bearing EAC showed significant decrease in cell viability compared to control. The total leukocyte, neutrophil, lymphocyte counts were increased as compared with EAC group. Vaccines would seem to trigger immunologic memory and thus subsequent treatments that are capable of up regulating tumour-associated antigen expression (Ridolfi et al., 2010). From an immunologic perspective, many cancer vaccines have been shown to induce significant specific humeral or T-cell responses to the tumour antigens being targeted, and some have induced levels of CD8 T cells approaching those seen in response to foreign pathogenic viruses (Berinstein, 2007).

Prop co injected with irradiated cancer vaccine by restoring significantly the haematological parameters towards normal, exhibits its therapeutic role on haematopoietic system. Also, the results showed that significantly restored the MDA, AOPP as well as GSH and SOD in blood and liver tissues of EAC bearing mice as compared to Irr-V group. Cytotoxic effect of Prop treated group and irradiated tumour cell lysate vaccine made a decrease in the viability of EAC cells, whereas the cytotoxicity effect of the co injected vaccine with prop made a significant decrease in the viability of EAC than each treatment alone.

Egypt. J. Rad. Sci. Applic., Vol. 27, No. 1-2 (2014) 
Stegel et al. (2006) demonstrated that the mature DCs could be efficiently maturated in vivo through vaccination of mice with irradiated tumour cells in combination with C-class $\mathrm{CpG}$ oligo-deoxynucletides (CpG ODN). Also they confirmed that processes triggered by this vaccination included the activation of the effectors of native immunity (phagocytes) as well as the activation of Cytotoxic T lymphocytes. However, the main cells influenced by the vaccine appeared to be the phagocytes, including the DCs and the main process their maturation (Novakovic et al., 2007). Cerkovnik et al. (2011) demonstrated that by the tumour vaccine composed of $\mathrm{CpG}$ ODN and irradiated tumour cell the antigen presenting cells, including the DCs are manipulated in vivo. By this kind of vaccine, the differentiation and maturation of antigen presenting cells (APCs) is triggered primarily in the spleen and is subsequently followed by the migration of these APCs to the bone marrow. Once in the bone marrow, these APCs (especially the DCs) play a crucial role in the development and maintenance of long-lived memory $\mathrm{T}$ cells capable of preventing a relapse of malignant disease.

In conclusion: Prop extract as an adjuvant with irradiated tumour cell lysate vaccine reduces haematological toxicities, decrease Lipid peroxides and AOPP levels in serum and liver, improves blood and liver GSH content, SOD activity induced by EAC, restrains oxidative stress and prevents injuries. The present study provides details about the effect of prop extract as an adjuvant with irradiated tumour cell lysate vaccine in EAC-bearing mice, suggesting that it could be a potential therapeutic agent for cancer therapy, though the mechanism of the thought effect is not yet clear.

\section{References}

Abdel-Hady, F. K. (1994) Gas Chromatography-Mass spectrometry (GC /MS) study of the Egyptian propolis-2-flavonoid constituents. Egypt. J. Appl. Sci., 9, 91.

Abou-Bedair, F. A., Hori, H., Nagasawa, H., Uto, Y., Abu-Zeid, M. and Inayama, S. (2002) Comparison of hypoxic cell radiosensitizers, KIN-804, KIN-844, KIN-806 and TX-1877, on brain and liver metabolizing capacities in mice bearing Ehrlich ascites carcinoma. Biologic. Pharmaceut. Bullent., 25, 591.

Andersen, M. H., Sørensen, R. B., Schrama, D., Svane, I. M., Becker, J. C. and Thor Straten, P. (2008) Cancer treatment: the combination of vaccination with other therapies. Cancer Immunol. Immunother., 57, 1735.

Badr El-Din, N. (2004) Protective role of sanumgerman against $\gamma$-irradiation-induced oxidative stress in Ehrlich carcinoma-bearing mice. Nutr. Res., 24, 271.

Egypt. J. Rad. Sci. Applic., Vol. 27, No. 1-2 (2014) 
Badr, M. O., Edrees, N. M., Abdallah, A. A., El-Deen, N. A., Neamat-Allah, A. N. and Ismail, H. T. ( 2011) Anti-tumour effects of Egyptian propolis on Ehrlich ascites carcinoma. Vet. Ital., 47, 341.

Berinstein, N. L. (2007) Enhancing cancer vaccines with immunomodulators. Vaccine, 27, 72-88.

Beutler, E., Duron, O. and Kelly, B. (1963) Improved method for determination of blood glutathione. J. Lab. Clin. Med., 61, 882.

Cai, J. L., Tang, X. L., Yang, L. F. and Su, X. Y. ( 2001) Propolis inactivated vaccine against infectious serositis in young ducks. Chin .J. Vet. Sci., 21, 552.

Cerkovnik, P., Jezersek Novakovic, B., Stegel, V. and Novakovic, S. (2011) Tumor vaccine composed of $\mathrm{CpG}$ ODN class $\mathrm{C}$ and irradiated tumor cells upregulates the expression of genes characteristic of mature dendritic cells and of memory cells. Int. J. Oncol., 38, 1749.

Chan, G. C., Cheung, K. W. and Sze, D. M. (2013) The immunomodulatory and anticancer properties of propolis. Clin. Rev. Allergy Immunol., 44, 262.

Dalgado, E. I. (2002) Cancer vaccines. The Oncologist., 7, 20.

Deacon, D. H., Hogan, K. T., Swanson, E. M., Chianese-Bullock , K. A., Denlinger, C. E., Teague, M. W. and Slingluff, C. L. (2008) The use of gammairradiation and ultraviolet-irradiation in the preparation of human melanoma cells for use in autologous whole-cell vaccines. BMC Cancer, 8, 360.

DeGowin, R. L. and Gibson, D. P. (1978) Suppressive effects of an extramedullary tumor on bone marrow erythropoiesis and stroma. Exp. Hematol., 6, 568.

Fischer, G., Cleff, M. B., Dummer, L. A., Paulino, N., Paulino, A., de Oliveira, Vilela C., Campos, F., Storch, T., de Oliveira and Vidor, T. (2007) Adjuvant effect of green propolis on humoral immune response of bovines immunized with bovine herpesvirus type 5. Vet. Immunol. Immunopathol., 116, 79.

Freimoster, F. M., Jkob, C. A., Aebi, M. and Tuor, U. (1999) The MTT [3, (4,5)Dimethylthiazol-2-yl) -2, 5-Diphenyltetrazolium bromide] assay is a fast and reliable method for calorimetric determination of fugal cell densities. Appl. Environ. Microbiol,. 65, 3727.

Gupta, A., Butts, B., Kwei, K. A., Dvorakova, K., Stratton, S. P., Briehl, M. M. and Bowden, G. T. (2001) Attenuation of catalase activity in the malignant phenotype plays a functional role in an in vitro model for tumor progression. Cancer Lett. 173, 115.

Guruvayoorappan, C. and Kuttan, G. (2007) Immunomodulatory and antitumor activity of Biophytum sensitivum extract. Asian Pac. J. Cancer Prev., 8, 27.

Hashem, M. A., Mohamed, H. M. and Magda, S. H. (2004) Clinico pathological,pathological and biophysical studies on the effect of electromagnetic field on the Ehrlich tumour cells implanted in mice. Egypt. J. Comp. Pathol. Clin. Pathol., 17, 117.

Egypt. J. Rad. Sci. Applic., Vol. 27, No. 1-2 (2014) 
Hoffman, R. M. (1985) Altered methionine metabolism and transmethylation in cancer. Anticancer Res., 5, 1.

Ishihara, M., Naoi, K., Hashita, M., Itoh, Y. and Suzui, M. (2009) Growth inhibitory activity of ethanol extracts of Chinese and Brazilian propolis in four human colon carcinoma cell lines. Oncol. Rep. 22, 349-354.

Keshavarz, M., Mostafaie, A., Mansouri, K., Shakiba, Y., Motlagh, H. R. (2009) Inhibition of corneal neovascularization with propolis extract. Arch. Med. Res., 40, 59.

Li, F., Awale, S., Zhang, H., Tezuka, Y., Esumi, H. and Kadota, S. (2009) Chemical constituents of propolis from Myanmar and their preferential cytotoxicity against a human pancreatic cancer cell line. J. Nat. Prod., 72, 1283.

Minami, M. and Yoshikawa, H. (1979) A simplified assay method of superoxide dismutase activity for clinical use. Clin. Chim. Acta., 92, 337.

Ming, L., Jill, C. P., Jingfang, J. N., Edward, C. and Brash, E. (1998) Antioxidant action via p53 mediated apoptosis. Cancer Res., 58, 1723.

Moreadith, R. W. and Lehninger, A. L. (1984) The pathways of glutamate and glutamine oxidation by tumor cell mitochondria. Role of mitochondrial NAD(P)+-dependent malic enzyme. J. Biol. Chem., 259, 6215.

Najafi, M. F., Vahedy, F., Seyyedin, M., Jomehzadeh, H. R. and Bozary, K. ( 2007) Effect of the water extracts of propolis on stimulation and inhibition of different cells. Cytotechnology., 54, 49.

Nakajima, Y., Tsuruma, K., Shimazawa, M., Mishima, S. and Hara, H. (2009) Comparison of bee products based on assays of antioxidant capacities. BMC. Complement Altern. Med., 26, 9.

Novakovic, S., Stegel, V., Kopitar, A., Ihan, A. and Jezersek Novakovic, B. (2007) Preventive and therapeutic effect of tumor vaccine composed of CpG ODN class $\mathrm{C}$ and irradiated tumor cells is triggered through the APCs and activation of CTLs. Vaccine, 25, 8241.

Orsolic, N., Kosalec, I., Basic, I. (2005) Synergistic antitumor effect of polyphenolic components of water soluble derivative of propolis against Ehrlich ascites tumour. Biol. Pharm. Bull., 28, 694.

Orsolic, N., Saranovic, A. B. and Basic, I. (2006) Direct and indirect mechanism(s) of antitumour activity of propolis and its polyphenolic compounds. Planta. Med., 72, 20.

Pandya, N. B., Tigari, P., Dupadahalli, K., Kamurthy, H. and Nadendla, R. R. (2013) Antitumor and antioxidant status of Terminalia catappa against Ehrlich ascites carcinoma in Swiss albino mice. Indian J. Pharmacol., 45, 464.

Pecorino, L. (2005) Molecular biology of Cancer. Mechanisms, targets and therapeutics. $3^{\text {ed }}$ ed., Oxford press, pp. 119-134.

Egypt. J. Rad. Sci. Applic., Vol. 27, No. 1-2 (2014) 
Popova, M., Dimitrova, R., Al-Lawati, H. T., Tsvetkova, I., Najdenski, H. and Bankova, V. (2013) Omani propolis: chemical profiling, antibacterial activity and new propolis plant sources. Chem. Cent. J., 7, 158.

Ravid, A. and Korean, R. (2003) The role of reactive oxygen species in the anticancer activity of vitamin D. Anticancer Res., 164, 357.

Ridolfi, L., Petrini, M., Fiammenghi, L., Granato, A., Ancarani, V., Pancisi, E., Scarpi, E., Guidoboni, M., Migliori, G., Sanna, S., Tauceri, F., Verdecchia, G., Riccobon, A., and Ridolfi, R. (2010) Unexpected high response rate to traditional therapy after dendritic cell-based vaccine in advanced melanoma. Clin. Dev. Immunol., 50, 4979.

Rowland-Jones, S.L. and McMichael, A. J (2000) Lymphocytes. A practical approach. $2^{\text {ed }}$ ed. editor: Hames, B.D. pp. 3-5.

Sato, J., Matsuda, S., Yabe, T., Usui, K. and Noda, M. (1961) Tissue culture of Ehrlich ascites tumor cells. Bull. Cancer Inst. Okayama Univ. Medic. School, 1,42 .

Scazzocchio, F., D'Auria， F. D., Alessandrini， D. and Pantanella， F. (2006) Multifactorial aspects of antimicrobial activity of propolis. Microbiol. Res., 161, 327.

Schnurr, M., Galambos, P., Scholz, C., Then, F., Dauer, M., Endres, S. and Eigler, A. (2001) Tumor cell lysate-pulsed human dendritic cells induce a T-cell response against pancreatic carcinoma cells: an in vitro model for the assessment of tumor vaccines. Cancer Res., 61, 6445.

Sforcin, J. M. (2007) Propolis and the immune system: a review. J. Ethnopharmacol., 113,1 .

Shivhare, S. C., Patidar, A. O., Malviya, K. G. and Shivhare-Malviya, K. K. (2011) Antioxidant and anticancer evaluation of Scindapsus officinalis (Roxb.) Schott fruits. Ayu., 32, 388.

Stegel, V., Kopitar, A., Jezersek Novakovic, B., Ihan, A. and Novakovic S. (2006) Dendritic cells incubated with irradiated tumor cells effectively stimulate T lymphocyte activation and induce enhanced expression of CD69, CD25 as well as production of IFNgamma and IL4. Int. Immunopharmacol., 6, 79.

Stuehr, D. J. and Nathan, C. F. (1989) Nitric oxide. A macrophage product responsible for cytostasis and respiratory inhibition in tumor target cells. $J$. Exp. Med., 169, 1543.

Sun, Y., Peterson, T. E., McCormick, M. L., Oberley, L. W. and Osborne, J. W. (1989) Improved superoxide dismutase assay for clinical use. Clin. Chem., $\mathbf{3 5}$, 1265.

Suthanthiran, M., Anderson, M. E., Sharma, V. K. and Meister, A. (1990) Glutathione regulates activation-dependent DNA synthesis in highly purified

Egypt. J. Rad. Sci. Applic., Vol. 27, No. 1-2 (2014) 
normal human $\mathrm{T}$ lymphocytes stimulated via the $\mathrm{CD} 2$ and $\mathrm{CD} 3$ antigens. Proc. Natl. Acad. Sci., 87, 3343.

Tan-No, K., Nakajima, T., Shoji, T., Nakagawasai, O., Niijima, F., Ishikawa, M., Endo, Y., Sato, T., Satoh, S. and Tadano, T (2006) Anti-inflammatory effect of propolis through inhibition of nitric oxide production on carrageenin-induced mouse paw edema. Biol. Pharm. Bull., 29, 96.

Toreti, V. C., Sato, H. H., Pastore, G. M. and Park, Y. K. (2013) Recent progress of propolis for its biological and chemical compositions and its botanical origin. Evid. Based Complement Alternat. Med., 2013, 697390

Valente, M. J., Baltazar, A. F., Henrique, R., Estevinho, L. and Carvalho, M. (2011) Biological activities of Portuguese Propolis: protection against free radical-induced erythrocyte damage and inhibition of human renal cancer cell growth in vitro. Food Chem. Toxicol., 49, 86.

Witko-Sarsat, V., Friedlander, M., Nguyen, Khoa, T., Capeillère-Blandin, C., Nguyen, A. T., Canteloup, S., Dayer, J. M., Jungers, P., Drueke, T. and Descamps-Latscha, B. (1998) Advanced oxidation protein products as novel mediators of inflammation and monocyte activation in chronic renal failure. J. Immuno., 161, 2524.

Wleklik, M., Zahorska, R. and Luczak, M. (1987) Interferon-inducing activity of flavonoids. Acta Microbiol. Pol., 36, 151.

Yagi, K. (1987) Lipid peroxides and human diseases. Chem. Phys. Lipids 45, 337.

Yoshioka, T., Kawada, K., Shimada, T. and Mori, M. (1979) Lipid peroxidation in maternal cord blood and protective mechanism against activated oxygen toxicity in blood. Am. J. Obstet. Gynecol., 135, 372.

Zhang, J. L., Wang, K., Hu and Hu, F. L. (2013) Advance in studies on antioxidant activity of propolis and its molecular mechanism. China J. Chinese Mater. Medica, 38, 645.

(Received: 06/04/2014;

accepted: 03/06/2014)

Egypt. J. Rad. Sci. Applic., Vol. 27, No. 1-2 (2014) 


\section{تأثير مستخلص صـخ النحل المصرى كمـادة محفزة مـع لقاح القداح

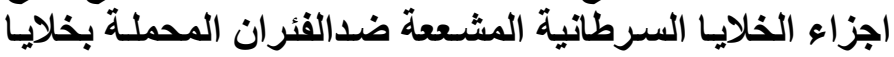 ارليخ السرطانية الخلية صفوت فريد سلامة ، و اسماء ابوبكر الصديق حسن

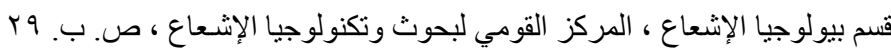

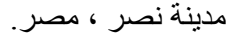

صمغ النحل هو مادة لزجة تجمع بو اسطة النحل من النباتات ـوكانت تستخدم قديما

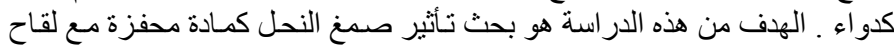

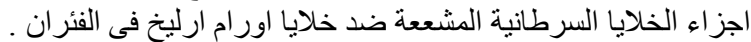

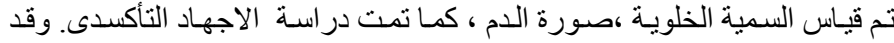

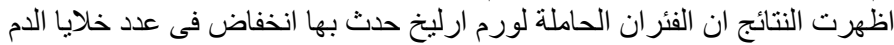

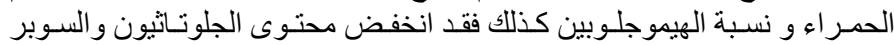

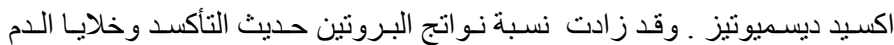

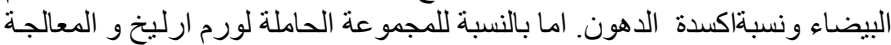

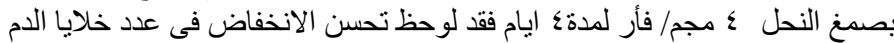

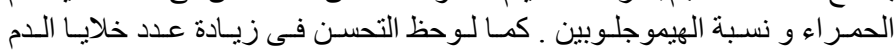

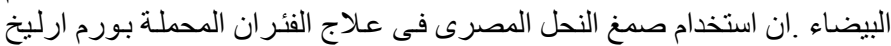

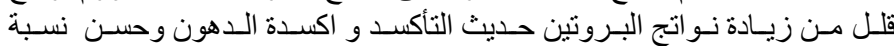

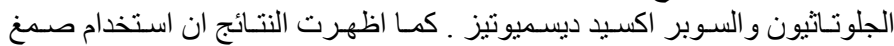

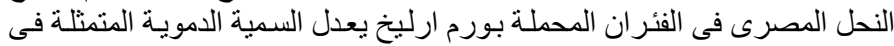

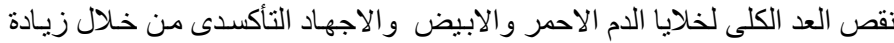

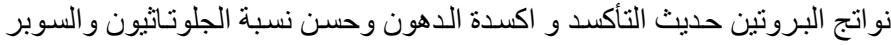

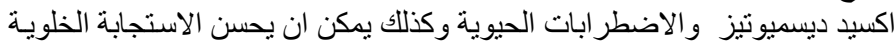

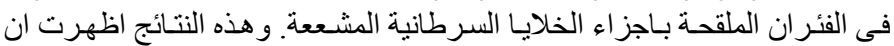

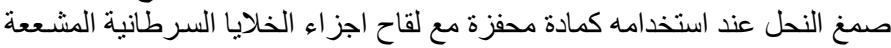
بعطى نتائج افضل من استخدام اللقاح فقط .

Egypt. J. Rad. Sci. Applic., Vol. 27, No. 1-2 (2014) 